\title{
Structural studies of an emulsion-stabilizing exopolysaccharide produced by an adhesive, hydrophobic Rhodococcus strain
}

\author{
T. R. Neu, ${ }^{2 *}$ T. Dengler, ${ }^{1}$ B. JANN ${ }^{1}$ and K. Poralla ${ }^{2}$ \\ ${ }^{1}$ Max-Planck-Institute for Immune Biology, Stübeweg 51, 7800 Freiburg, Germany \\ ${ }^{2}$ Botanical Institute, Microbiology, University of Tübingen, Auf der Morgenstelle 1, 7400 Tübingen 1, Germany
}

(Received 12 June 1992; revised 28 July 1992; accepted 26 August 1992)

\begin{abstract}
The primary structure of an emulsion-stabilizing exopolysaccharide from the adhesive, hydrophobic Rhodococcus strain No. 33 was elucidated by NMR spectroscopy, methylation analyses, periodate oxidation and oligosaccharide analyses. The polysaccharide PS-33 consisted of rhamnose, galactose, glucose and glucuronic acid in molar ratios of 2:1:1:1. The main chain contained 3-substituted $\alpha$-D-glucuronic acid linked to the 3-position at $\alpha$-L-rhamnose, in addition to 3-substituted residues of $\beta$-D-galactose and $\alpha$-D-glucose. The $\alpha$-L-rhamnose of the side chain was linked to position 4 of the galactose. In addition, the polysaccharide was $O$-acetylated, corresponding to one acetyl group per repeating unit. From the results two structural possibilities could be suggested. As the polysaccharide carries hydrophobic groups (methyl of rhamnose/ $O$-acetyl), it is very likely that these are of general significance for the emulsifying activity of polysaccharides. It also seems to be possible that this polysaccharide is at least partially responsible for the hydrophobic cell surface properties of the Rhodococcus strain No. 33 and it may be involved in hydrophobic interactions when adhering to hydrophobic interfaces.
\end{abstract}

\section{Introduction}

Polysaccharides, as bacterial cell surface compounds, have a broad range of functions in the ecology of microorganisms at interfaces (Christensen, 1989; Neu, 1992a). In addition, micro-organisms are able to produce a great variety of other interfacial-active molecules, among them lipids, biosurfactants and polymeric emulsifiers (Haferburg et al., 1986; Rosenberg, 1986). However, the literature contains only a few reports of emulsionstabilizing polysaccharides (Cirigliano \& Carman, 1985; Cooper et al., 1980; Fattom \& Shilo, 1985; Floodgate, 1978; Käppeli \& Fiechter, 1977; Kaplan \& Rosenberg, 1982; Kaplan et al., 1985; Zajic et al., 1974, 1977a, b; Zuckerberg et al., 1979). With the exception of emulsifiers from two Acinetobacter calcoaceticus strains, most of these polysaccharides are not well characterized. Emulsan from Acinetobacter calcoaceticus RAG-1 has been the subject of numerous studies, but to the authors' knowledge, the structure has not been published. To date, only the structure of the polysaccharide component

* Author for correspondence. Present address: Laboratory for Materia Technica, Antonius Deusinglaan 1, University of Groningen, 9713 AV Groningen, The Netherlands. Fax 3150633159. of the emulsifier produced by Acinetobacter calcoaceticus BD-4 has been published (Kaplan et al., 1985).

The polysaccharide PS-33 described in this study was produced by the adhesive, hydrophobic Rhodococcus strain No. 33 (Neu \& Poralla, 1988) which was isolated in an enrichment of hydrophobic bacteria from freshwater (Neu \& Poralla, 1987). In this screening, bacterial strains were isolated which produced low-molecular-mass biosurfactants as well as high-molecular-mass emulsifiers (Neu \& Poralla, 1990; Neu et al., 1990). One of the isolated polymeric emulsifiers was identified as polysaccharide and further characterized. This polysaccharide revealed surface-active properties as determined by different methods (Neu \& Poralla, 1988). Here we present the quantitative composition and structural studies of the emulsion-stabilizing exopolysaccharide PS-33 produced by the adhesive, hydrophobic Rhodococcus strain No. 33 .

\section{Methods}

Bacteria and cultivation. The isolation (Neu \& Poralla, 1987) and identification (Neu \& Poralla, 1988) of Rhodococcus strain No. 33 were described previously. The strain was kept as a stock culture on silica gel at $-20^{\circ} \mathrm{C}$. The bacteria were activated on agar and then inoculated into $10 \mathrm{ml}$ medium ( $100 \mathrm{ml}$ Erlenmeyer flask) as a preculture which was 
used to grow the bacteria in $100 \mathrm{ml}$ medium ( $500 \mathrm{ml}$ Erlenmeyer flask) The bacteria were cultured at $20^{\circ} \mathrm{C}$ by rotation at a speed of 120 r.p.m. (Gyrotory incubator, New Brunswick).

To isolate the exopolysaccharide PS- 33 the bacteria were cultured in a 201 fermenter (Biolafitte type $\mathrm{C} 6$ ) at $25^{\circ} \mathrm{C}$, stirring rate 300 r.p.m., aeration $21 \mathrm{~min}^{-1}$. Medium: $4.8 \mathrm{~g} \mathrm{~K}_{2} \mathrm{HPO}_{4} .3 \mathrm{H}_{2} \mathrm{O}, 1.5 \mathrm{~g} \mathrm{KH}_{2} \mathrm{PO}_{4}$, $1.0 \mathrm{~g}\left(\mathrm{NH}_{4}\right)_{2} \mathrm{SO}_{4}, 0.5 \mathrm{~g}$ trisodium citrate $2 \mathrm{H}_{2} \mathrm{O}, 0.2 \mathrm{~g} \mathrm{MgSO}_{4} .7 \mathrm{H}_{2} \mathrm{O}$, 0.1 g yeast extract, $2.0 \mathrm{mg} \mathrm{CaCl} 2.2 \mathrm{H}_{2} \mathrm{O}, 0.4 \mathrm{mg} \mathrm{MnCl} 2.4 \mathrm{H}_{2} \mathrm{O}, 0.4 \mathrm{mg}$ $\mathrm{NiCl}_{2} .6 \mathrm{H}_{2} \mathrm{O}, 0.4 \mathrm{mg} \mathrm{ZnSO}_{4} .7 \mathrm{H}_{2} \mathrm{O}, 0.2 \mathrm{mg} \mathrm{FeCl}_{3} .6 \mathrm{H}_{2} \mathrm{O}, 0.2 \mathrm{mg}$ $\mathrm{Na}_{2} \mathrm{MoO}_{4} \cdot 2 \mathrm{H}_{2} \mathrm{O}, 11$ distilled water, $\mathrm{pH} 7 \cdot 2$. Instead of glucose $\left(2 \mathrm{~g} \mathrm{l}^{-1}\right)$ as in the media in which the polysaccharide PS-33 was first discovered in small amounts (Neu \& Poralla, 1990), hexadecane $(2.5 \%, \mathrm{v} / \mathrm{v})$ was added as a carbon source. The fermenter was started with a $2.5 \%(\mathrm{v} / \mathrm{v})$ inoculum from a $93 \mathrm{~h}$ preculture.

Isolation of polysaccharide PS-33. After $140 \mathrm{~h}$, the bacteria were harvested using a tangential flow filtration system equipped with a $0.5 \mu \mathrm{m}$ HVLP 000 C 5 filter (Millipore). The clear filtrate was precipitated with $75 \%(\mathrm{w} / \mathrm{v})$ ammonium sulphate at $4{ }^{\circ} \mathrm{C}$ overnight. The precipitate was centrifuged $(8000 \mathrm{~g})$, redissolved in water, dialysed extensively against distilled water and lyophilized. To remove the remaining hexadecane, the polysaccharide was extracted four times with chloroform/methanol $(1: 1, v / v)$, monitored by GC. Protein was digested with pronase $\mathrm{E}$ (Serva) in distilled water at $40^{\circ} \mathrm{C}$ overnight $\left(20 \mathrm{mg} \mathrm{ml}^{-1}\right.$ PS-33, $100 \mu \mathrm{g} \mathrm{ml}^{-1}$ pronase E). After dialysis, the polysaccharide was lyophilized. Gel permeation chromatography was done using Sepharose $C L 4 B$, with a fractionation range of $3 \times 10^{4}-5 \times 10^{6}$, in $0.2 \mathrm{M}$-ammonium acetate buffer. The production of antibodies against the isolated polysaccharide was described elsewhere (Neu \& Poralla, 1988).

Analytical methods. Rhamnose, galactose and glucose were determined by GC as alditol acetates (Sawardeker et al., 1965) after hydrolysis in $1 \mathrm{M}-\mathrm{HCl}$ at $100^{\circ} \mathrm{C}$ for $16 \mathrm{~h}$. GC analyses were run on an ECNSS-M (ethylene succinate-cyanoethyl silicon polymer) column using a Varian Aerograph series 1400 equipped with a HewlettPackard integrator $3380 \mathrm{~A}$. Glucuronic acid was determined with the carbazole/sulphuric acid reagent (Dische, 1962). D-Glucose and D-galactose were determined with D-glucose oxidase and D-galactose oxidase (Boehringer Mannheim), respectively. $O$-Acetyl groups were determined by $\mathrm{GC}$ after hydrolysis with $0.05 \mathrm{M}-\mathrm{NaOH}$ for four hours as described by Fromme \& Beilharz (1978).

High voltage paper electrophoresis was performed at $45 \mathrm{~V} \mathrm{~cm}^{-1}$ for $1 \mathrm{~h} \mathrm{in} \mathrm{acetic} \mathrm{acid/pyridine/water}(4: 10: 86, \mathrm{v} / \mathrm{v} / \mathrm{v}) \mathrm{pH} 5 \cdot 3$. Electropherograms were stained with silver nitrate according to Trevelyan et al. (1950). Infra-red (IR) spectra were recorded with a Perkin Elmer Infracord spectrophotometer. Protein was determined with an amino acid analyser (Durrum-500) after hydrolysis in $4 \mathrm{M}-\mathrm{HCl}$ at $100{ }^{\circ} \mathrm{C}$ for $18 \mathrm{~h}$.

Combined GC/MS was performed on a 1020 B Finnigan mass spectrometer employing a CP Sil 5 capillary column. Smith degradation and methylation analyses were performed as described in the literature (Goldstein et al., 1965; Hakomori, 1964; Hungerer et al., 1967; Lindberg et al., 1972; Reske \& Jann, 1972).

${ }^{13} \mathrm{C}$-NMR (75.47 MHz) and ${ }^{1} \mathrm{H}-\mathrm{NMR}(300 \mathrm{MHz}$ ) spectroscopy was performed with a Bruker WM 300 spectrophotometer in Fouriertransform mode. Spectra were run at $70^{\circ} \mathrm{C}$ with sodium 3-trimethylsilyl- $\left(2,2,3,3^{-2} \mathrm{H}\right)$ propionate (TSP) as external standard. The chemical shift values were corrected (subtraction of 1.31 p.p.m. ${ }^{13} \mathrm{C}-\mathrm{NMR}$ and of 0.07 p.p.m. $\left.{ }^{1} \mathrm{H}-\mathrm{NMR}\right)$ by measuring dioxan $(\delta=67.4$ p.p.m. based on tetramethylsilane) so that they could be directly compared with those obtained using a tetramethylsilane reference. The anomeric configurations were determined by NMR spectroscopy and chromium trioxide oxidation (Hoffman et al., 1972).

All experiments were repeated at least twice to confirm reproducibility. Representative results are shown in Tables and Figures.

\section{Results}

\section{Isolation and characterization of PS-33}

The purified polysaccharide was obtained from liquid culture in a yield of $158 \mathrm{mg} \mathrm{l}^{-1}$. Gel permeation chromatography showed that PS-33 was eluted in the void volume, indicating a high-molecular-mass polysaccharide. The polysaccharide consisted of rhamnose, galactose, glucose and glucuronic acid in molar ratios of approximately $2: 1: 1: 1$. In addition, the polysaccharide was $O$-acetylated $(6 \%)$, which corresponds to one acetyl group per repeating unit. De- $O$-acetylation was monitored by IR spectrometry.

The occurrence of the exopolysaccharide in the capsule was determined with antibodies against the isolated exopolysaccharide. The antibodies agglutinated the bacterial cells and also precipitated the isolated polysaccharide. Comparison of the polysaccharide yield and composition from glucose- and hexadecane-grown cells revealed that bacteria which have been cultured with the hydrophobic substrate released the polysaccharide PS-33 into the culture media. This was in accordance with electron micrographs of gelatine-embedded bacterial cells which showed an extended capsule when grown on glucose and no capsule when grown on hexadecane.

\section{Isolation of the disaccharide DS-33}

After hydrolysis of PS-33 in $1 \mathrm{M}-\mathrm{HCl}$ at $100{ }^{\circ} \mathrm{C}$ for $0.5 \mathrm{~h}$ an acidic disaccharide (DS-33) was isolated by preparative high-voltage paper electrophoresis. Its electrophoretic mobility relative to glucuronic acid was $\mathbf{0 . 7 2}$. Following purification by chromatography on Bio-Gel P-2, the disaccharide DS-33 was obtained in a yield of $17 \%$.

\section{Methylation analyses}

The de- $O$-acetylated PS-33 was methylated with a modified Hakomori procedure. In addition, the methylated polysaccharide was carboxyl-reduced with $\mathrm{LiAlD}_{4}$. The interpretation of the mass spectra obtained with the partially methylated alditol acetates is shown in Table 1. It was found that PS-33 contained a 3-linked glucuronic acid, a 3-linked rhamnose, a 3-linked glucose, a 3,4-disubstituted galactose and a terminal rhamnose.

The isolated disaccharide DS-33 was reduced with sodium borohydride before methylation and directly subjected to GC/MS. The mass spectrum and fragmentation pattern of the reduced and permethylated disaccharide DS-33 presented in Fig. 1 showed the typical $J_{1}$ fragment of $m / z=265$. This indicated that the disaccharide was identical with glucuronosyl-( $1 \rightarrow 3)$-rhamnose. 
Table 1. Methylation analysis of the polysaccharide PS-33

\begin{tabular}{llll}
\hline \hline Signal & $\mathrm{R}_{\mathrm{Glc}}{ }^{*}$ & \multicolumn{1}{c}{$\begin{array}{c}\text { Characteristic mass } \\
\text { fragments }(\mathrm{m} / \mathrm{z})\end{array}$} & \multicolumn{1}{c}{ Interpretation } \\
\hline A & $\mathbf{0} 49$ & $115,117,131,161,175$ & 1,5-di- $O$-acetyl-6-deoxy-2,3,4-tri- $O$-methylhexitol \\
$\mathrm{B}$ & $1 \cdot 02$ & $117,131,201,233,247$ & $1,3,5$-tri- $O$-acetyl-6-deoxy-2,4-di- $O$-methylhexitol \\
$\mathrm{C}$ & $1 \cdot 91$ & $117,161,233,277$ & $1,3,5$-tri- $O$-acetyl-2,4,6-tri- $O$-methylhexitol \\
$\mathrm{D}$ & $3 \cdot 52$ & 117,305 & $1,3,4,5$-tetra- $O$-acetyl-2,6-di- $O$-methylhexitol \\
$\mathrm{E}$ & $4 \cdot 46$ & $117,131,191,233,307$ & $1,3,5,6$-tetra- $O$-acetyl-2,4-di- $O$-methylhexitol-6-d \\
\hline \hline
\end{tabular}

* $\mathrm{R}_{\mathrm{Glc}}$, retention time on an ECNSS-M column relative to 1,5-di-O-acetyl-2,3,4,6-tetra- $O$-methylglucitol.

(a)

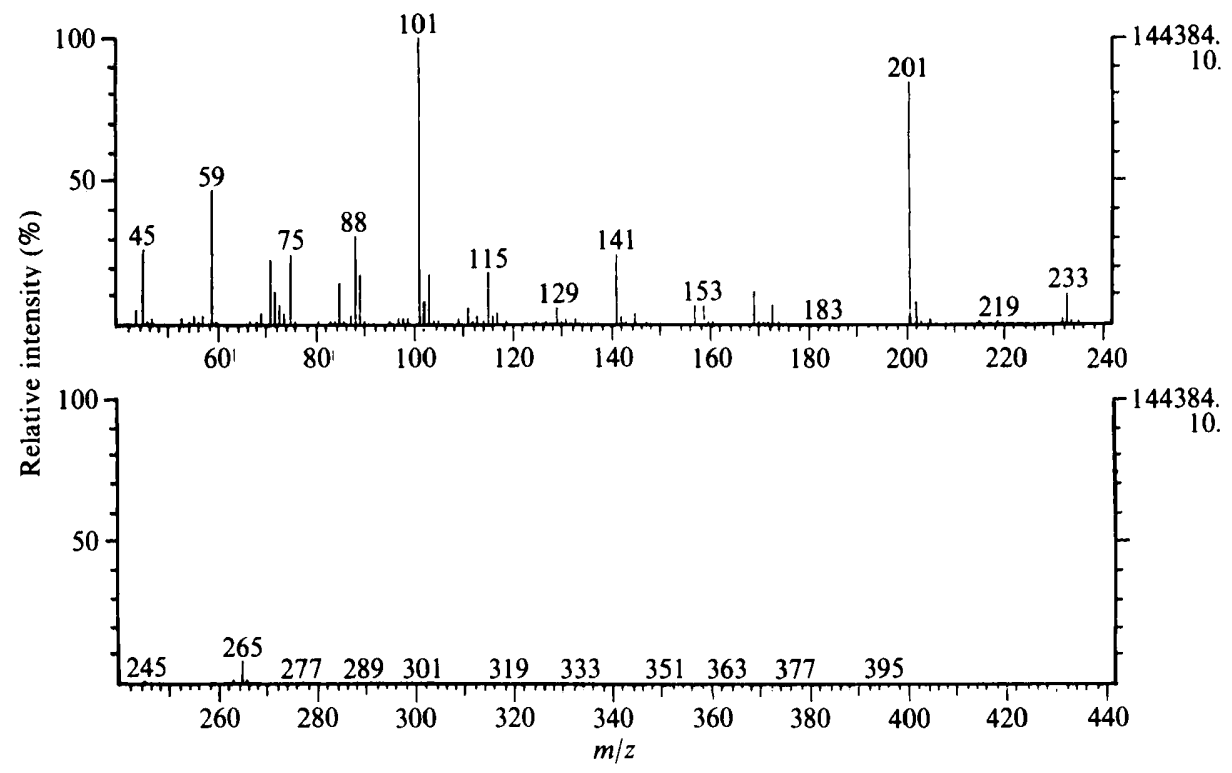

(b)

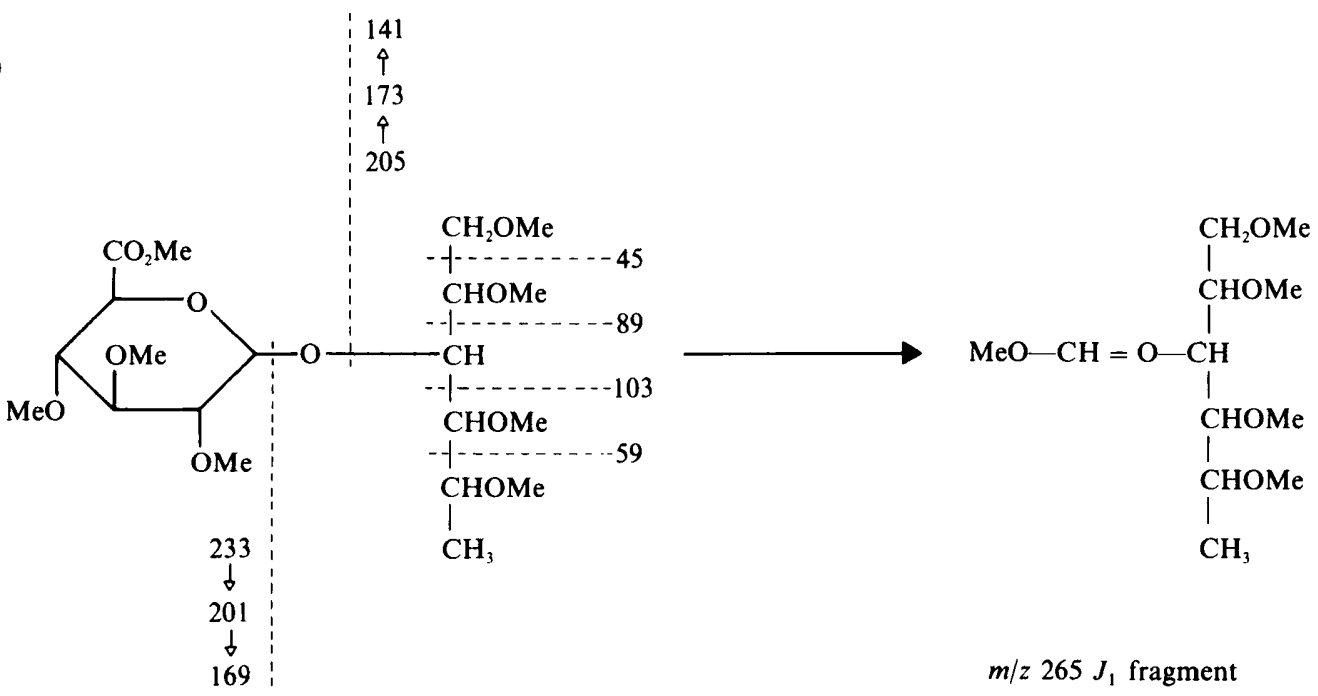

Fig. 1. Mass spectrum $(a)$ and fragmentation pattern $(b)$ of glucuronosyl-(1 $\rightarrow 3)$-rhamnose (DS-33). 


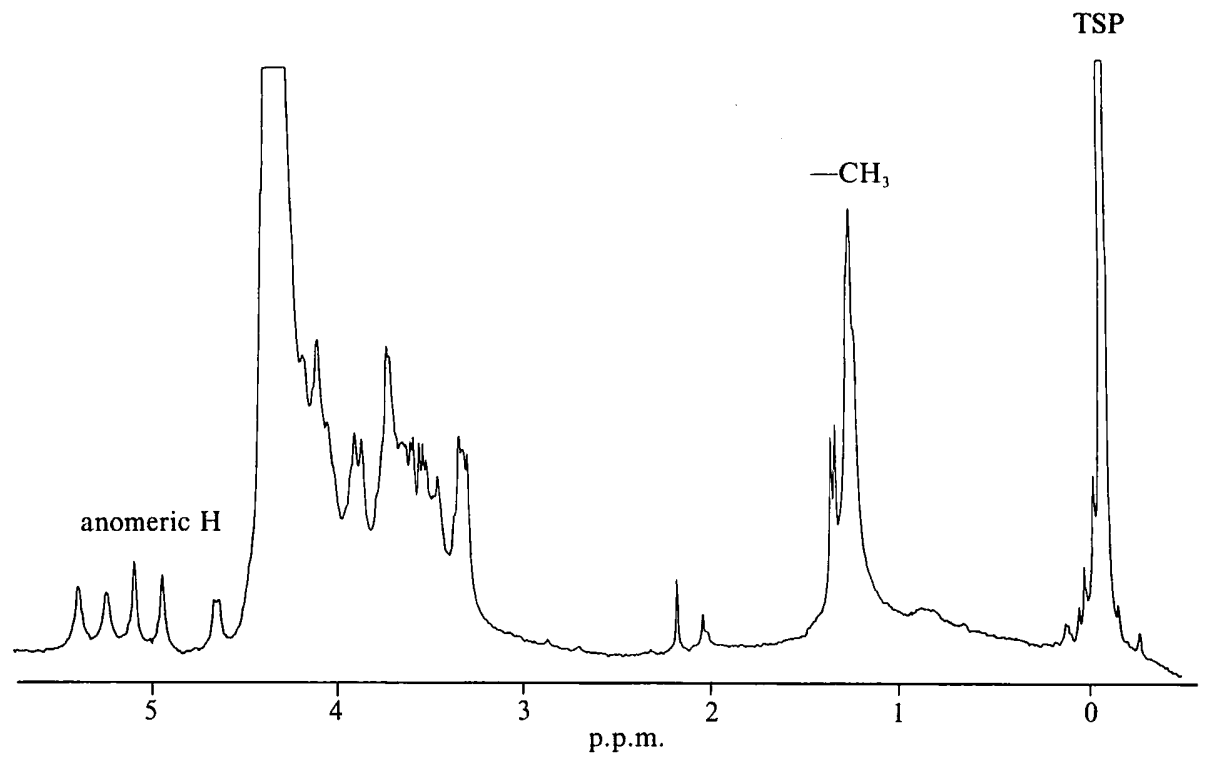

Fig. 2. ${ }^{1} \mathrm{H}-\mathrm{NMR}$ spectrum of the de- $\mathrm{O}$-acetylated polysaccharide $\mathrm{PS}-33$ in $\mathrm{D}_{2} \mathrm{O}$ at $70{ }^{\circ} \mathrm{C}$. TSP, sodium trimethylsilyl- $\left({ }^{2} \mathrm{H}_{4}\right)$ propionate used as external reference.
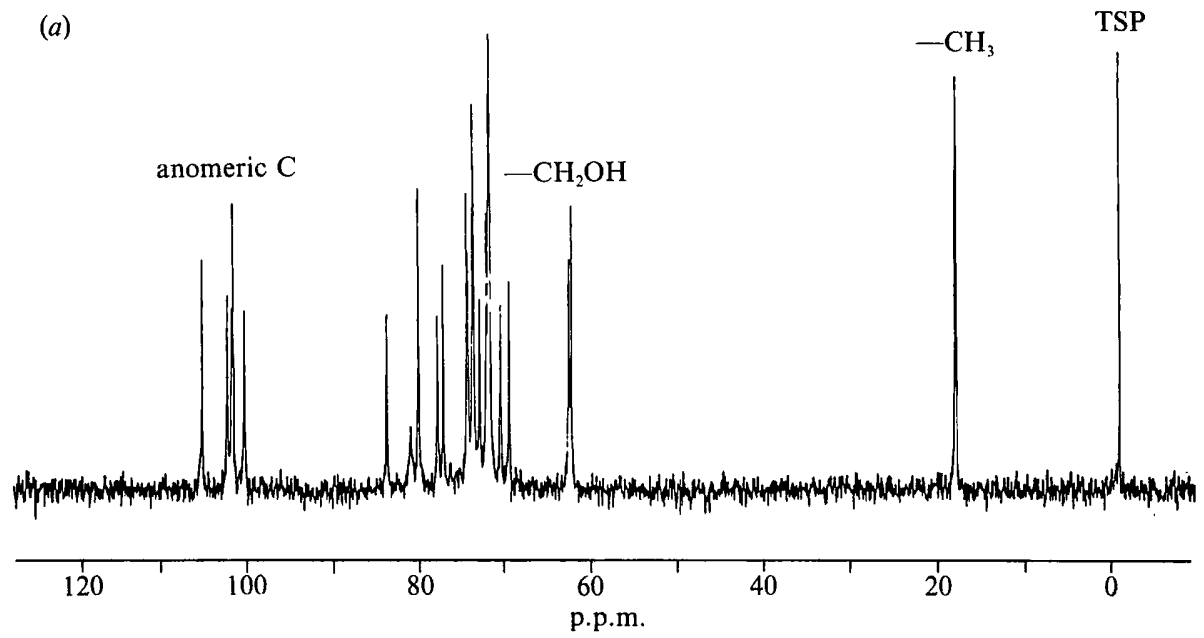

(b)

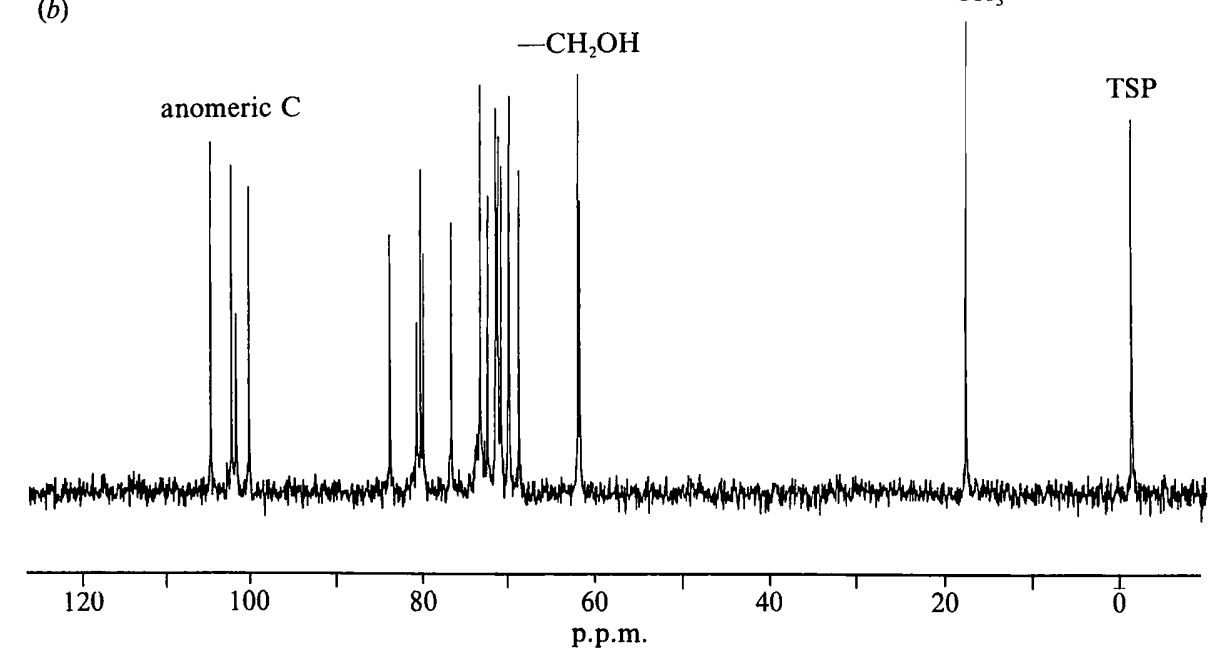

Fig. $3 .{ }^{13} \mathrm{C}$-NMR spectra of the de-O-acetylated polysaccharide $\mathrm{PS}-33$ in $\mathrm{D}_{2} \mathrm{O}$ at $70{ }^{\circ} \mathrm{C}$. TSP, sodium trimethylsilyl-( $\left({ }^{2} \mathrm{H}_{4}\right)$ propionate used as external reference. (a) Before oxidation with sodium metaperiodate. (b) After oxidation and Smith hydrolysis. 


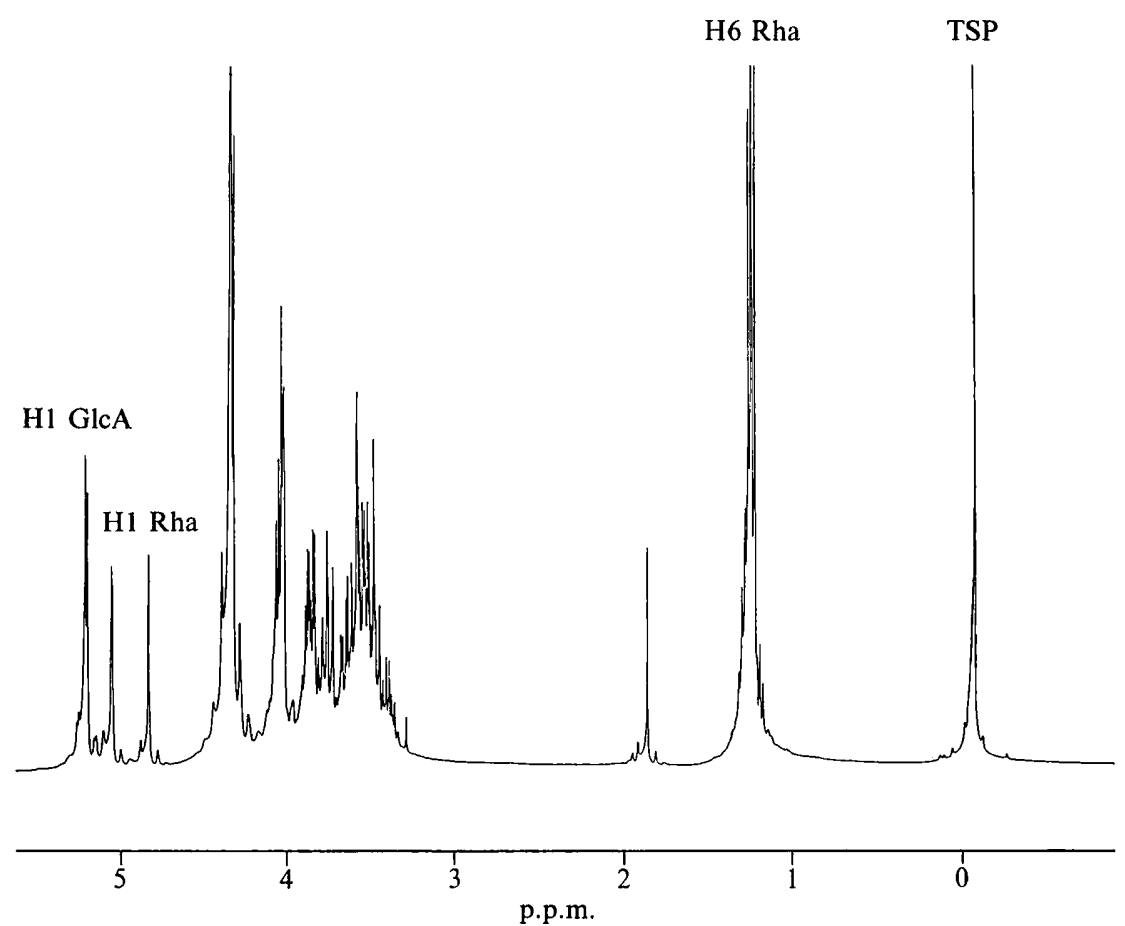

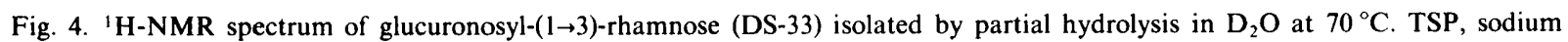
trimethylsilyl- $\left({ }^{2} \mathrm{H}_{4}\right)$ propionate used as external reference.

\section{NMR spectroscopy}

For NMR spectroscopy, the polysaccharide PS-33 was de- $O$-acetylated. The signals of the ${ }^{1} \mathrm{H}$-NMR spectrum in the anomeric region $(4.62,4.93,5.08,5.23$ and 5.38 p.p.m.) indicated the presence of 5 sugars in the repeating unit. The multiple signals at 1.24 p.p.m. can be assigned to H-6 of the two rhamnose units (Fig. 2). In Fig. 3(a), the ${ }^{13} \mathrm{C}-\mathrm{NMR}$ spectrum of PS-33 is shown. The signals in the anomeric region $(99.9,101.2,101.4,101.9$ and 104.8 p.p.m.) were due to $\mathrm{C}-1$ of glucuronic acid, glucose, galactose and two rhamnose units. The signals at 61.8 and 62.1 p.p.m. were due to the primary hydroxyl group at C-6 of glucose and galactose, and those at 17.51 and 17.57 p.p.m. were due to the methyl groups of the two rhamnose residues. The ${ }^{1} \mathrm{H}-\mathrm{NMR}$ spectrum of the isolated disaccharide DS-33 is presented in Fig. 4. Based on published literature values, the signals at 5.17 and 5.19 p.p.m. were assigned to $\mathrm{H}-1$ of glucuronic acid. The doublets at 5.02/5.03 p.p.m. and at $4 \cdot 805 / 4.808$ p.p.m. were due to $H-1$ of $\alpha$ - and $\beta$-anomers of the reducing rhamnose. The multiple signals at 1.23 p.p.m. were due to $\mathrm{H}-6$ of rhamnose.

\section{Smith degradation of the polysaccharide}

To analyse the linkage pattern of the 3,4-disubstituted galactose, the PS-33 was subjected to a Smith degradation which removed the side-chain rhamnose. The periodate-oxidized and borohydride-reduced PS-33 was hydrolysed with $1 \%(\mathrm{v} / \mathrm{v})$ acetic acid $(16 \mathrm{~h}$ at room temperature and $1 \mathrm{~h}$ at $100{ }^{\circ} \mathrm{C}$ ). The ${ }^{13} \mathrm{C}$-NMR spectrum of the polymer produced showed the absence of one signal in the anomeric region (Fig. $3 b$ ). A second oxidation with sodium metaperiodate resulted in no further chemical alteration of PS-33, as shown by an unchanged ${ }^{13} \mathrm{C}$-NMR spectrum.

\section{Anomeric configurations}

The ${ }^{1} \mathrm{H}$-NMR spectrum of the disaccharide glucuronosyl-(1 $\rightarrow 3)$-rhamnose showed a coupling constant $J_{\mathrm{H}-1, \mathrm{H}-2}=3.79$ for glucuronic acid. ${ }^{1} \mathrm{H}-\mathrm{NMR}$ spectra of the polysaccharide PS-33 revealed coupling constants of $J_{\mathrm{H}-1, \mathrm{H}-2}=3.5$ for glucose and glucuronic acid, $J_{\mathrm{H}-1, \mathrm{H}-2}=7 \cdot 5$ for galactose and no coupling for rhamnose. As chromium trioxide destroys peracetylated $\beta$-glycosides but not peracetylated $\alpha$-glycosides, this method was also used to determine the configurations of neutral sugars in the polysaccharide. The GC determination showed that the content of galactose decreased to about $50 \%$ of its original value.

\section{Discussion}

The exopolysaccharide of the hydrophobic Rhodococcus strain No. 33 consists of rhamnose, galactose, glucose and glucuronic acid in the molar ratio of $2: 1: 1: 1$. 
Furthermore, it contains $O$-acetyl groups. It is not known whether the acetyl groups are distributed regularly (one per repeating unit) or whether certain regions of the polysaccharide are more densely acetylated than others. The latter substitution pattern would result in domains of differing hydrophobicity.

Methylation analyses indicated that glucuronic acid, rhamnose and glucose are linked at position 3, galactose at positions 3 and 4 and that one rhamnose is a nonreducing terminus. Thus PS- 33 is a branched polysaccharide, with rhamnose linked to galactose in the main chain. By partial hydrolysis the acidic disaccharide DS-33 was obtained and methylated. The fragmentation pattern on MS of methylated disaccharide DS-33 shows that it is the disaccharide glucuronosyl-( $(1 \rightarrow 3)$-rhamnose.

The ${ }^{1} \mathrm{H}-\mathrm{NMR}$ and ${ }^{13} \mathrm{C}-\mathrm{NMR}$ spectra of the polysaccharide verified a repeating unit consisting of a pentasaccharide. In particular, an integration of the ${ }^{1} \mathrm{H}-\mathrm{NMR}$ spectrum revealed a $1: 1: 1: 1: 1$ ratio of the sugar constituents. After removal of the side-chain rhamnose by Smith degradation, the remaining unbranched PS-33 was resistant to periodate oxidation. This indicates that all main-chain sugars are 1,3-linked, and that rhamnose is linked to position 4 of galactose.

The anomeric configuration of glucuronic acid was apparent from ${ }^{1} \mathrm{H}$-NMR of the disaccharide glucuronosyl-(1 $\rightarrow 3)$-rhamnose, indicating $\alpha$-glucuronic acid (Dutton \& Folkman, 1980). The coupling constants derived from ${ }^{1} \mathrm{H}-\mathrm{NMR}$ spectra of the polysaccharide PS-33 revealed $\alpha$-glucose, $\alpha$-glucuronic acid and $\beta$-galactose as well as the $\alpha$-configuration of rhamnose. For neutral sugars, chromium trioxide oxidation showed that galactose is the only sugar of the repeating unit with a $\beta$-configuration.

Since the linkages in the polysaccharide backbone were all $(1 \rightarrow 3)$ and no further di- or oligosaccharide could be isolated, the position of glucose in the backbone remained unclear. Thus, from the above results two structural possibilities could be suggested (Fig. 5).

To date, only very few emulsifying polysaccharides have been investigated in detail, among them two produced by Acinetobacter (Rosenberg \& Kaplan, 1987). The first, emulsan from Acinetobacter calcoaceticus RAG-1 (Zuckerberg et al., 1979), is a polysaccharide with covalently bound fatty acids distributed across the whole molecule. This is in contrast to lipopolysaccharides or lipoteichoic acids where the lipid part is bound to one end of the molecule. The second, an emulsifying polysaccharide from Acinetobacter calcoaceticus BD4 (Kaplan et al., 1985), is only active when it is reconstituted with a protein (Kaplan et al., 1987). PS-33 of Rhodococcus strain No. 33 is a further polysaccharide possessing emulsifying activity from which the structure has been elucidated.

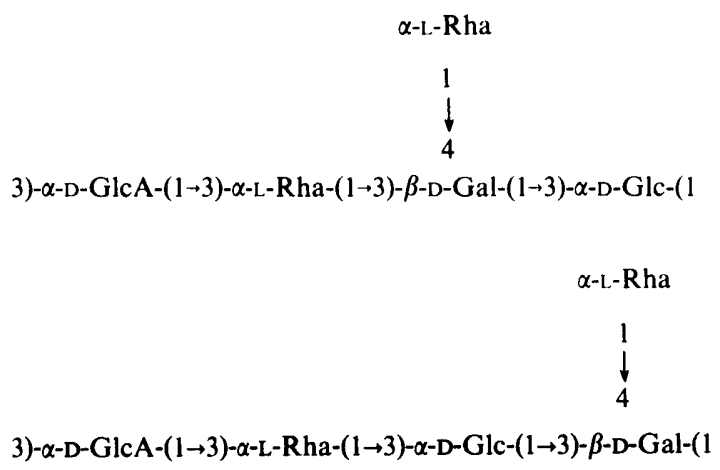

Fig. 5. Structural possibilities for the emulsifying polysaccharide PS-33 produced by the adhesive, hydrophobic Rhodococcus strain No. 33. In addition, the polysaccharide was $O$-acetylated, corresponding to one acetyl group per repeating unit.

Polysaccharide PS-33 contains 6-deoxy sugars in the form of rhamnose not only in the backbone but also in the side chain of the repeating unit. In addition, PS-33 is acetylated. It seems possible that the presence of methyl groups (of the 6-deoxy sugars) and of $O$-acetyl is of general importance for the emulsifying activity of polysaccharides.

Similar findings were reported for the marine Pseudomonas sp. NCMB 2021 which releases a polysaccharide at the end of the exponential growth phase. This polysaccharide is also rich in deoxy sugars as well as acetyl groups and showed unusual solubility properties. Its solubility in high concentrations of phenol, methanol and ethanol could be explained by these hydrophobic groups (Christensen et al., 1985). For other microbial polysaccharides a certain degree of surface activity could be measured by employing surface tension measurements (Symes, 1982). Surface tension and light scattering measurements of PS-33 (Neu et al., in preparation) indicated a similar potential for surface activity in this polysaccharide as was reported by Symes (1982).

Since the capsulated Rhodococcus strain No. 33 was isolated on the basis of cell surface hydrophobicity, we suppose that its polysaccharide contributes to or may be a major cause of cell surface hydrophobicity. This would indicate a role for polysaccharides rich in deoxy sugars in the adhesion of bacteria to hydrophobic interfaces (Neu \& Marshall, 1990). Furthermore it is possible that polysaccharides carrying hydrophobic groups are involved in the labelling of hydrophobic interfaces by micro-organisms (Neu \& Marshall, 1991; Neu, 1992b; Rosenberg \& Kaplan, 1987).

We are obliged to Miss $H$. Kochanowski for running the NMR spectra and to Mr D. Borowiak for the mass spectra. This work was supported by the Deutsche Forschungsgemeinschaft Po 117/10-1 and 10-2. 


\section{References}

Christensen, B. E. (1989). The role of extracellular polysaccharides in biofilms. Journal of Biotechnology 10, 181-202.

Christensen, B. E., Kuosbakken, J. \& Smidsrod, O. (1985). Partial chemical and physical characterization of two extracellular polysaccharides produced by marine, periphytic Pseudomonas sp. strain NCMB 2021. Applied and Environmental Microbiology 50, 837-845.

Cirigliano, M. C. \& Carman, G. M. (1985). Purification and characterization of liposan, a bioemulsifier from Candida lipolytica. Applied and Environmental Microbiology 50, 846-850.

COOPER, D. G., ZAJIC, J. E. \& WoOD, J. M. (1980). The emulsifying and de-emulsifying properties of some microbial polysaccharides. Acta Biotechnologica 0, 21-25.

Dische, Z. (1962). Color reactions of 6-deoxy-, 3-deoxy-, and 3,6dideoxy-hexoses. Methods in Carbohydrate Chemistry 1, 497-501.

DutTon, G. G. S. \& FolkmaN, T. E. (1980). Structural investigation of the capsular polysaccharide of Klebsiella serotype K17. Carbohydrate Research 80, 147-161.

FatTom, A. \& ShILo, M. (1985). Production of emulcyan by Phormidium J-1: its activity and function. FEMS Microbiology Ecology 31, 3-9.

FLOODGATE, G. D. (1978). The formation of oil emulsifying agents in hydrocarbonclastic bacteria. In Microbial Ecology, pp. 82-85. Edited by M. W. Loutit \& J. A. R. Miles. New York: Springer-Verlag.

Fromme, I. \& BEILHARZ, H. (1978). Gas chromatographic assay of total and $O$-acetyl groups in bacterial lipopolysaccharides. Analytical Biochemistry 84, 347-353.

Goldstein, I. J., Hay, G. W., Lewis, B. A. \& Smith, F. (1965). Controlled degradation of polysaccharides by periodate oxidation, reduction and hydrolysis. Methods in Carbohydrate Chemistry 5, 361-370.

Haferburg, D., Hommel, R., Claus, R. \& Kleber, H.-P. (1986). Extracellular microbial lipids as biosurfactants. Advances in Biochemical Engineering/Biotechnology 33, 53-93.

HAKOMORI, S. (1964). A rapid permethylation of glycolipid, and polysaccharide catalyzed by methylsulfinyl carbanion in dimethyl sulfoxide. Journal of Biochemistry (Tokyo) 55, 205-208.

Hoffman, J., LindBerg, B. \& Svensson, S. (1972). Determination of the anomeric configuration of sugar residues in acetylated oligo- and polysaccharides by oxidation with chromium trioxide in acetic acid. Acta Chemica Scandinavica 26, 661-666.

HUNGERER, D., JANN, K., JANN, B., ORSKov, F. \& ORSKov, I. (1967). Immunochemistry of $\mathrm{K}$ antigens of Escherichia coli. 4. The $\mathrm{K}$ antigen of E. coli O9: K 30:H12. European Journal of Biochemistry 2, 115-126.

KÄPPELI, O. \& FIECHTER, A. (1977). Component from the cell surface of the hydrocarbon-utilizing yeast Candida tropicalis with possible relation to hydrocarbon transport. Journal of Bacteriology 131, 917-921.

Kaplan, N. \& Rosenberg, E. (1982). Exopolysaccharide distribution of and bioemulsifier production by Acinetobacter calcoaceticus BD4 and BD413. Applied and Environmental Microbiology 44, 1335-1341.

Kaplan, N., RosenberG, E., JaNN, B. \& JanN, K. (1985). Structural studies of the capsular polysaccharide of Acinetobacter calcoaceticus BD4. European Journal of Biochemistry 152, 453-458.

Kaplan, N., Zosim, Z. \& Rosenberg, E. (1987). Reconstitution of emulsifying activity of Acinetobacter calcoaceticus BD4 emulsan by using pure polysaccharide and protein. Applied and Environmental Microbiology 53, 440-446.
LindBerg, B., LöNNGREN, J., THOMPSON, J. L. \& NimMich, W. (1972). Structural studies of the Klebsiella type 9 capsular polysaccharide. Carbohydrate Research 25, 49-57.

NeU, T. R. (1992a). Polysaccharide in Biofilmen. In Jahrbuch Biotechnologie Band 4, pp. 73-101. Edited by P. Präve, M. Schlingman, W. Crueger, K. Esser, R. Thauer \& F. Wagner. München: Carl Hanser Verlag.

NEU, T. R. (1992b). Microbial 'footprints' and the general ability of micro-organisms to label interfaces. Canadian Journal of Microbiology 38, (in the Press).

Neu, T. R. \& Marshall, K. C. (1990). Bacterial polymers: physicochemical aspects of their interactions at interfaces. Journal of Biomaterials Applications 5, 107-133.

NeU, T. R. \& Marshall, K. C. (1991). Microbial 'footprints' - a new approach to adhesive polymers. Biofouling 3, 101-112.

NeU, T. R. \& Poralla, K. (1987). Screening for bacteria with hydrophobic surfaces - a strategy for isolating surface-active molecules. In Proceedings of the 4th European Congress on Biotechnology, Amsterdam, vol. 3, pp. 397-399. Edited by O. M. Neijssel, R. R. van der Meer \& K. C. A. M. Luyben. Amsterdam: Elsevier.

NeU, T. R. \& Poralla, K. (1988). An amphiphilic polysaccharide from an adhesive Rhodococcus strain. FEMS Microbiology Letters 49, 389-392.

Neu, T. R. \& Poralla, K. (1990). Emulsifying agents from bacteria isolated during screening for cells with hydrophobic surfaces. Applied Microbiology and Biotechnology 32, 521-525.

Neu, T. R., HÄrtner, T. \& Poralla, K. (1990). Surface active properties of viscosin: a peptidolipid antibiotic. Applied Microbiology and Biotechnology 32, 518-520.

RESKE, K. \& JANN, K. (1972). The O8-antigen of E. coli, structure of the polysaccharide chain. European Journal of Biochemistry 31, 320328.

Rosenberg, E. (1986). Microbial surfactants. CRC Critical Reviews in Biotechnologv 3, 109-132.

Rosenberg, E., \& KaPLAN, N. (1987). Surface-active properties of Acinetobacter exopolysaccharides. In Bacterial Outer Membranes as Model Systems, pp. 311-342. Edited by M. Inouye. New York: John Wiley.

SAWARDeker, J. S., Sloneker, J. H. \& Jeanes, A. (1965). Quantitative determination of monosaccharides as their alditol acetates by gas liquid chromatography. Analytical Chemistry 37, 1602-1604.

SYMES, K. C. (1982). Lipophilic polysaccharides. Carbohydrate Polymers 2, 276-281.

Trevelyan, W. E., Proctor, D. P. \& Harrison, J. S. (1950) Detection of sugars on paper chromatograms. Nature, London 166, 444-445.

Zajic, J. E., Supplisson, B. \& Volesky, B. (1974). Bacterial degradation and emulsification of No. 6 fuel oil. Environmental Science and Technology 8, 664-668.

Zajic, J. E., Guignard, H. \& Gerson, D. F. (1977a). Emulsifying and surface active agents from Corynebacterium hydrocarboclastus. Biotechnology and Bioengineering 19, 1285-1301.

Zailc, J. E., Guignard, H. \& Gerson, D. F. (1977b). Properties and biodegradation of a bioemulsifier from Corynebacterium hydrocarboclastus. Biotechnology and Bioengineering 19, 1303-1320.

Zuckerberg, A., Diver, A., Peeri, Z., Gutnick, D. L. \& Rosenberg, E. (1979). Emulsifier of Arthrobacter RAG1 : chemical and physical properties. Applied and Environmental Microbiology 37, 414-420. 